\title{
Isolation and characterization of metal-resistant bacterial strain from wastewater and evaluation of its capacity in metal-ions removal using living and dry bacterial cells
}

\author{
Y. Benmalek ${ }^{1} \cdot$ M.-L. Fardeau ${ }^{2}$
}

Received: 11 January 2016/Revised: 13 April 2016/ Accepted: 27 June 2016/Published online: 13 July 2016

(C) Islamic Azad University (IAU) 2016

\begin{abstract}
A novel strain of the genus Micrococcus isolated from wastewater was studied for resistance to seven heavy metals and forty antibiotics. Its capacity to accumulate metal ions was also realized at different $\mathrm{pH}$. The strain exhibited high minimal inhibitory concentration values for metal ions tested and resist to 15 antibiotics. The living cells of the bacterial strain show a largest uptake capacity at $\mathrm{pH}$ 6-8.5 for copper, nickel, and zinc with values ranging from 51.45 to $83.90 \%, 52.59$ to $78.81 \%$, and 59.55 to $78.90 \%$, respectively. It was also able to absorbed $59.81-80.08 \%$ of chromium and $58.09-79.41 \%$ of cobalt at $\mathrm{pH} 7.3-8.5$. The maximum lead uptake was obtained at pH 5.5-8.5 with an amount of 55.28-91.06\%. The significant absorption of cadmium was shown at $\mathrm{pH} 6.5$ with $38 \%$. In $25 \mu \mathrm{g} \mathrm{mL}-1$ zinc, chromium, and nickel solutions, dead cells of the isolate were able to biosorbed 20.46, 22.5 , and $23.98 \mu \mathrm{g} \mathrm{mL}^{-1}$, respectively, after $30 \mathrm{~min}$ of contact. In other solutions with higher concentrations 50 and $100 \mu \mathrm{g} \mathrm{mL}^{-1}$, the amount of each metal immobilized was, respectively, as follows: 38.02 and $90.21 \mu \mathrm{g} \mathrm{mL}^{-1}$ for zinc, 39.78 and $89.23 \mu \mathrm{g} \mathrm{mL}^{-1}$ for chromium, and 47.19 and $86.83 \mu \mathrm{g} \mathrm{mL}^{-1}$ for nickel. Due to its high-metal accumulation capacity in aerobic conditions, these Grampositive bacteria may be potentially applicable in situ
\end{abstract}

M.-L. Fardeau

marie-laure.fardeau@univ-amu.fr

1 Laboratoire de Microbiologie, Département de BCM, Faculté des Sciences Biologiques, Université des Sciences et de la Technologie Houari Boumediene, Bab Ezzouar, Alger, Algeria

2 Aix-Marseille Université, Université du Sud Toulon-Var, CNRS/INSU, IRD, MIO, UM 110, 13288 Marseille, France bioremediation of heavy metals contaminating aqueous systems.

Keywords Gram-positive bacteria - Antibiotics · Heavy metals $\cdot$ Resistance $\cdot$ Accumulation

\section{Introduction}

Heavy-metal pollution of the environment has dramatically increased in recent years due to various human activities, such as agriculture, mining, and various other industrial processes (Rajaganapathy et al. 2011). The presence of significant concentrations of these toxic elements in environment ecosystems leads to both contamination of soil and water and deleterious impact on environment life (Rajbanshi 2008). Heavy metals are recognised to be powerful inhibitors of biodegradation activities (Deeb and Altalhi 2009). These chemical elements can not be degraded and are ultimately indestructible. The toxic effects of metal ions result mainly from their interaction with proteins and inhibition of metabolic processes (Tamil Selvi et al. 2012). Though some heavy metals, such as copper, nickel, chromium, and zinc are using as micronutrients for development and growth of organisms, however, others, such as cadmium, mercury, and lead, have no physiological activity for the cell. Moreover, the higher concentrations of these toxic elements above threshold levels have a very detrimental effect on the microbial communities and their vital activities (Ahemad and Malik 2012). Thus, microbial populations exposed to heavy metals present in the environment contain bacteria which have acquired a variety of mechanism for adaptation and resistance to these toxic elements, and, among them, bioaccumulation which involves complexation of the metal ions inside and outside 
the cell with biosorption (Johncy et al. 2010), mineralisation and precipitation, enzymatic oxidation or reduction of the toxic metals, and the efflux systems of metal ions outside the cell (Nies 2003). Wastewaters are usually hazardous to human populations and the various environmental ecosystems and must be treated prior to disposal into rivers, seas, and land surfaces (Bashan and Bashan 2010). Although, the removal of these toxic compounds from them is a real challenge for waste treatment engineers and scientists (Wang et al. 2010). The traditional biological treatment processes can eliminate a large fraction of biodegradable organics compound existed in wastewater. Furthermore, the biological treatment cost is much lower than that of physical and chemical methods (Kumar et al. 2011). Thus, the heavy-metal removal ability of metal-resistant bacteria has been studied extensively and proposed to be efficient and economical alternative in uptake of heavy metal ions from wastewater (Vidali 2001).

This study deals with the characterization of the bacterial strain isolated from wastewater and testing its resistance to different heavy metal concentrations and antibiotics sensitivity. The ability of this bacterium to accumulate cadmium, lead, zinc, chromium, cobalt, copper, and nickel ions at different $\mathrm{pH}$ using living bacterial cells was evaluated and compared. Eventually, the biosorption of zinc, chromium and nickel was studied.

\section{Materials and methods}

The bacterium used in this study was the strain $2 \mathrm{YB}-25 \mathrm{OH}$ isolated from a sample of wastewater collected from Oued El Harrach in west of Algiers, Algeria, in 2010. It was identified on the basis of cells morphology, Gram-coloring, and study of some physiological and biochemical characteristics, such as respiratory type, catalase, oxydase, and nitrate reductase tests. The molecular identification of the isolate by the sequencingof $16 \mathrm{~S}$ rRNA was done in the laboratories IRD [France] and GATC [Germany].

\section{Bacterial heavy-metal resistance test and MIC determination}

The new strain was tested for its resistance to seven heavy metals by agar dilution method Malik and Ahemad (2006); Kinare and Shingadia 2014). However, stock solutions of $10^{4} \mu \mathrm{g} \mathrm{mL}^{-1}$ were prepared by dissolving the exact quantities of the following metal salts: $\mathrm{CdCl}_{2}$ (BIOCHEM), $\mathrm{ZnCl}_{2}$ (ANALAR), $\mathrm{Pb}\left(\mathrm{NO}_{3}\right)_{2}$ (BIOCHEM), $\mathrm{K}_{2} \mathrm{CrO}_{4}$ (MERCK), $\mathrm{Ni}\left(\mathrm{NO}_{3}\right)_{2} \cdot 6 \mathrm{H}_{2} \mathrm{O}$ (BIOCHEM), $\mathrm{CuCl}_{2}$ (PANREAC), and
$\mathrm{CoCl}_{2}$ (FLUKA) in distilled water and sterilized at $120{ }^{\circ} \mathrm{C}$ for $20 \mathrm{~min} .20 \mathrm{~mL}$ of nutrient agar was poured into Petri plates and the volume of metal stock solutions was calculated by the formula: $C_{1} \times V_{1}=C_{2} \times V_{2}$, where $C_{1}$ is the metal concentration in stock solution, $V_{1}$ is the volume of stock solution used, $C_{2}$ is the concentration of metal in agar, and $V_{2}$ is the volume of agar. Thereafter, the bacterial strain was streaked onto the medium-containing increasing concentrations of metal salts using sterile loops. Then, plates were sealed and incubated at $30{ }^{\circ} \mathrm{C}$ for 5 days. Plate-containing only nutrient agar was also inoculated and incubated to act as control. The lowest concentration of each metal at which no growth occurred when compared to the control plates was considered as the MIC.

\section{Heavy-metal accumulation and removal capacity of living bacterial cells}

Foremost, the evolution of the growth of the strain 2YB$25 \mathrm{OH}$ was monitored in the presence of metal ions at different pHs. Thereafter, the removal capacity of living bacterial cells was evaluated. In this context, the bacterial strain was grown in nutrient broth containing $100 \mu \mathrm{g} \mathrm{mL}$ of each metal at different pHs $(5,5.5,6,6.5,7.3,8$, and 8.5). The flasks were incubated in shaking conditions (130 rpm) at $30{ }^{\circ} \mathrm{C}$ for $48 \mathrm{~h}$ (Krishna et al. 2012; Sujitha and Jayanthi 2014; Abbas et al. 2014a, b). Two sets of controls crops were prepared simultaneously with the experiment flasks. The first one was prepared at different pHs and without heavy metals to measure bacterial growth and the second without bacterial biomass to evaluate the residual concentration of each metal. The growth was determined by measuring the optical density at $600 \mathrm{~nm}$ with uninoculated broth as control. However, the evaluation of the residual concentration of each metal was carried out after centrifugation at $6000 \mathrm{rpm}$ for $10 \mathrm{~min} 10 \mathrm{~mL}$ of each bacterial culture and analysis of the supernatant from each sample using Atomic Absorption Spectrometry as recommended by the American Public Health Association (1998).

\section{Study of metal-ions removal capacity of dry bacterial cells (Biosorption)}

To evaluate the capacity of zinc, chromium, and nickel adsorption by the isolate, $0.2 \mathrm{~g}$ of cell dry weight were added to $100 \mathrm{~mL}$ heavy-metal solutions of 25,50 , and $100 \mu \mathrm{g} \mathrm{mL}^{-1}$ in $250 \mathrm{~mL}$ flasks. The $\mathrm{pH}$ of the solutions was adjusted to 6.5 and incubation was performed under 
stirring $(130 \mathrm{rpm})$ at $30{ }^{\circ} \mathrm{C} .10 \mathrm{~mL}$ were removed from each flask after $30,60,90$, and 120 min of contact and centrifuged at $6000 \mathrm{rpm}$ for $10 \mathrm{~min}$. The supernatants were analyzed to determine metal ions concentrations using Atomic Absorption Spectrometry (AAS).

\section{Determination of antibiotic resistance}

The strain $2 \mathrm{YB}-25 \mathrm{OH}$ was tested for its sensitivity to 40 antibiotics using disk diffusion method (Bauer et al. 1966). A single colony was picked and inoculated in nutrient broth media. The culture was incubated at $30{ }^{\circ} \mathrm{C}$ for $24 \mathrm{~h}$. The turbidity of media was compared to the $0.5 \mathrm{McF}$ arland standard, then spread on Muller-Hinton agar using sterile swabs. Thereafter, antibiotic-impregnated discs were located on the surface of the plates. After $48 \mathrm{~h}$ of incubation at $30{ }^{\circ} \mathrm{C}$, the diameter of the inhibition zones was measured and the strain was classified as resistant (R), intermediate (I), and susceptible (S) following the standard antibiotic disk chart. The following antibiotic discs were tested: ampicillin (AM) $10 \mu \mathrm{g}$, oxacillin (OX) $5 \mu \mathrm{g}$, penicillin (P) $10 \mathrm{IU}$, amoxicillin (AMX) $25 \mu \mathrm{g}$, cefalexin $(\mathrm{CN})$ $30 \mu \mathrm{g}$, cefotaxim (CTX) $30 \mu \mathrm{g}$, cefoxitin (FOX) 30ug, cefalotin (CF) $30 \mu \mathrm{g}$, cefuroxim (CXM) $30 \mu \mathrm{g}$, piperacilline (PIP) $100 \mu \mathrm{g}$, carbenicillin (CB) $100 \mu \mathrm{g}$, fosfomycin (FOS) $50 \mu \mathrm{g}$, streptomycin (S) $10 \mu \mathrm{g}$, gentamycin (GM) $10 \mu \mathrm{g}$, kanamycin (K) $30 \mu \mathrm{g}$, amikacin (AN) 30ug, tobramycin (NN) $10 \mu \mathrm{g}$, neomycin (N) 30UI, netilmicin (Net) $30 \mu \mathrm{g}$, dibekacin (DKB) $10 \mu \mathrm{g}$, erythromycin (E) $15 \mu \mathrm{g}$, spiramycin (SP) $100 \mu \mathrm{g}$, nalidixic-acid (NA) $30 \mu \mathrm{g}$, pipemidique acid (Pi) $20 \mu \mathrm{g}$, ofloxacin (OFX) $5 \mu \mathrm{g}$, tetracyclin (TE) $30 \mu \mathrm{g}$, doxycyclin (DOX) 30ug, chloramphenicol (C) $30 \mu \mathrm{g}$, bacitracin (B) $10 \mathrm{IU}$, colistin $(\mathrm{Cl})$ $30 \mu \mathrm{g}$, lincomycine (L) $15 \mu \mathrm{g}$, furanes (FT) $300 \mu \mathrm{g}$, flumequin (UB) $30 \mu \mathrm{g}$, fusidic acid (FA) $10 \mu \mathrm{g}$, nitroxolin (Ni) $20 \mu \mathrm{g}$, nitofurantoin (F/M) $300 \mu \mathrm{g}$, vancomycin (VA) $30 \mu \mathrm{g}$, pristinamycin (PR) $15 \mu \mathrm{g}$, sulfamides (G) $200 \mu \mathrm{g}$, and rifampicine (RA) $30 \mu \mathrm{g}$.

\section{Results and discussion}

The strain 2YB-25OH was yellow pigmented with cells spherical-shaped and grouped into tetrad. It's Gram-positive, strictly aerobic, catalase and oxydase-positive, hydrolyze arginine, reduce nitrate to nitrite, non-motile, and do not form spores. It grew over a wide range of $\mathrm{pH}$ (3-10), temperature $\left(20^{\circ}-40^{\circ} \mathrm{C}\right)$, and $\mathrm{NaCl}$ concentration $(0.0-10 \%)$; the strain was halotolerant, as it grew in the presence of $10 \% \mathrm{NaCl}$, but did not require salt for its physiological activities. On account of morphological and biochemical characteristics, it was identified as Micrococcus sp. Analysis of $16 \mathrm{~S}$ rDNA sequence revealed that the strain $2 \mathrm{YB}-25 \mathrm{OH}$ is a novel strain of the genus

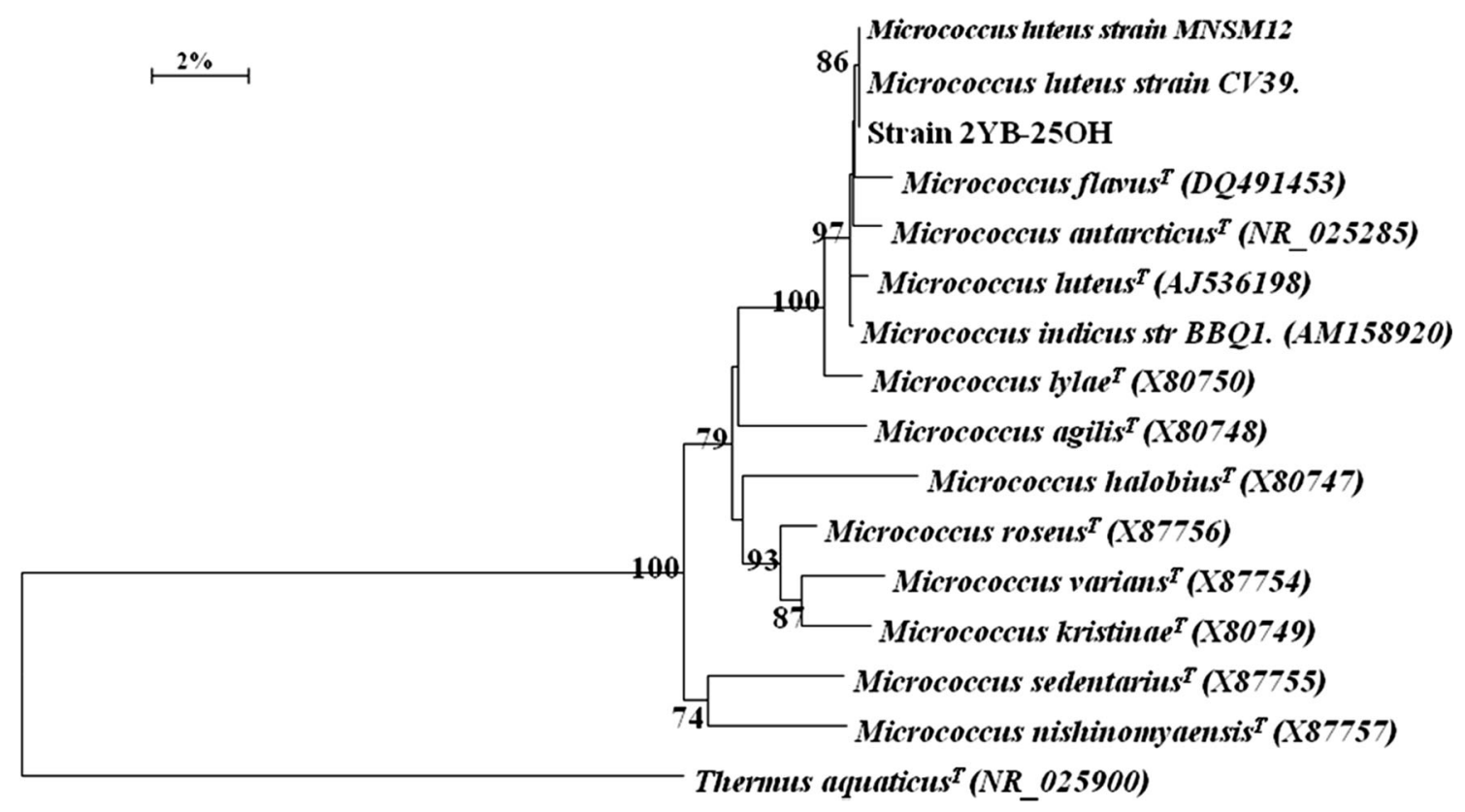

Fig. 1 Phylogenetic tree showing relation between Strain 2YB-25OH and other Micrococcus strains 
Micrococcus with $99 \%$ homology with Micrococcus luteus strains and was designated as Micrococcus luteus strain $2 \mathrm{YB}-25 \mathrm{OH}$. The phylogenetic position of the species is shown in Fig. 1.

\section{Determination of the MIC of heavy metals and antibiotic resistance}

The novel strain of Micrococcus luteus characterized and showed a varied level of resistance to heavy metals tested. Results obtained revealed a great deal of variation in resistance pattern of the promising isolate to each metal ion studied. However, the MIC levels against cadmium, nickel, copper, and zinc up to $300,350,400$, and $500 \mu \mathrm{g} \mathrm{mL}^{-1}$, respectively. It exhibited MIC towards chromium and cobalt up to 600 and $650 \mu \mathrm{g} \mathrm{mL}^{-1}$, respectively. The bacterium showed the maximum resistance against lead with MIC value $1400 \mu \mathrm{g} \mathrm{mL}^{-1}$. The resistance to metal ions may be attributed to some detoxifying mechanisms developed by this strain to rap out their toxicity, such as accumulation and complexation of the metal ions inside the cell, the efflux of metal ions outside the cell, adsorption by metal ions exchange on the cell surface, and reduction of some heavy metal to a less toxic state (Issazadeh et al. 2013; Lucious et al. 2013). Thus, cadmium resistance mechanism in Gram-positive bacteria is linked to cadmium efflux systems. However, the zinc resistance is achieved through the two general efflux mechanisms mediated by a P-type ATPase efflux system and an RND-driven transporters system (Spain and Alm 2003). Furthermore, resistance against copper is most often dependent upon efflux mechanism. Mancini et al. (2015) reported that P-type ATPases detoxify copper via efflux mechanism in some species. However, it has been reported that copper metabolism occurs naturally in all living organisms, and is generally chromosomally encoded (Ahemad 2012). In contrast, mechanisms that specify resistance to copper in bacteria is often plasmid encoded (Abicht et al. 2013). The plasmid and chromosomal systems may interact with each other to maintain copper homeostasis in bacteria ( $\mathrm{Lu}$ et al. 1999). Moreover, the copper resistance systems of the type, usually encode four proteins which bind copper in the periplasm or close to the outer membrane (Hans et al. 2016). Mikolay and Nies (2009) reported that nickel and cobalt resistance is linked to RND-driven outer membrane efflux system and cytoplasmic membrane efflux systems.

The behavior of the strain against antibiotics studied varies according to antibiotic families. Among 40 antibiotics tested, only 15 were active on the strain $2 \mathrm{YB}-25 \mathrm{OH}$ with a rate of $37.5 \%$. Total resistance $\left(R_{\mathrm{T}}\right)$ was observed against twelve antibiotics: cefalexin, cefuroxim, kanamycin, tetracyclin, piperacilline, tobramycin, furanes, flumequin, pipemidique acid, nalidixic-acid, nitrofurantoin, and fosfomycin with an intermediate resistance $\left(R_{\mathrm{I}}\right)$ to

Table 1 Antibiotic sensitivity and resistance of the strain 2YB-25OH

\begin{tabular}{|c|c|c|}
\hline Families and number of antibiotics tested & Resistant to & Sensitive to \\
\hline$\beta$ lactamins: (11) & $\begin{array}{l}\text { Cefalexin, Cefuroxim, } \\
\text { Piperacilline }\end{array}$ & $\begin{array}{l}\text { Penicillin, Ampicillin, Amoxicillin, } \\
\text { Oxacillin, Cefalotin, Cefotaxim, } \\
\text { Cefoxitin, Carbenicillin }\end{array}$ \\
\hline Aminosids: (08) & $\begin{array}{l}\text { Kanamycin, Tobramycin } \\
\text { Dibekacin }\left(\mathrm{R}_{\mathrm{I}}\right)\end{array}$ & $\begin{array}{l}\text { Gentamycin, Netilmicin, Neomycin } \\
\text { Streptomycin, Amikacin }\end{array}$ \\
\hline Tetracyclins: (2) & Tetracyclin & Doxyciclin \\
\hline Quinolons:03 & $\begin{array}{l}\text { Pipemidique acid, Ofloxacin }\left(\mathrm{R}_{\mathrm{I}}\right) \\
\text { Nalidixic-acid }\end{array}$ & \\
\hline Furans +Nitrofurans: $1+1$ & Furanes, Nitrofurantoin & \\
\hline Fosfomycin: 01 & Fosfomycin & \\
\hline Oxyquinoleines: 01 & Nitroxolin $\left(\mathrm{R}_{\mathrm{I}}\right)$ & \\
\hline Fluoroquinolones: 01 & Flumequin & \\
\hline Glycopeptides: 01 & & Vancomycine \\
\hline Fusidamins: 01 & & Fusidic acid \\
\hline Sulfamides et associés: 01 & & Sulfamides \\
\hline Macrolides: 02 & & Erythromycin, Spiramycin \\
\hline Lincosamides: 01 & & Lincomycine \\
\hline Phénicoles: 01 & & Chloramphenicol \\
\hline Rifamycines: 01 & & Rifampicine \\
\hline Polypeptides: 02 & & Bacitracin, Colistin \\
\hline Streptogramines: 01 & & Pristinamycine \\
\hline
\end{tabular}


dibekacin, ofloxacin, and nitroxolin (Table 1). Thus, the strain was found to be sensitive to a large number of antibiotics in particular the $\beta$ lactams. Sulaimon et al. (2015) reported that a strain of Micrococcus luteus isolated from Awotan Dumpsite Leachate in Nigeria had lowest resistance ability to drugs. It was sensitive to gentamycin, streptomycin, amoxicillin, rifampicine, erythromycin, and ciprofloxacin. These results were partially in agreement with our own. Based on the results of other researchers, the high sensitivity of $M$. luteus to $\beta$-lactam antibiotics may be due to the presence of some reduced set, such as a penicillin-binding proteins and the absence of a $w b l C$ gene, which plays an important role in the antibiotic resistance in other actinobacteria (Morris et al. 2005).

\section{Study of the effect of heavy metals on the bacterial growth}

As shown in Fig. 2, the strain 2YB-25OH exhibited different growth patterns in the presence of $100 \mu \mathrm{g} \mathrm{mL}^{-1}$ of different heavy metals. The shape of the growth curves of the Gram-positive bacteria was relatively close to the control growth curve. However, a decrease in growth (measured in terms of optical density) was observed compared to the control without metal amendment. The lower optical density values obtained with cadmium and cobalt revealed that the bacterial growth was extremely affected by these metal ions in the growth medium. Ranquet et al. (2007) reported that iron-sulfur proteins were greatly affected in cobalt-treated bacteria cells and have demonstrated experimentally that elevated intracellular concentration of cobalt leads to the inactivation of three selected iron-sulfur enzymes. However, cobalt toxicity was attributed to cobalt-thiol group interaction of enzymes. Eventually, some authors have reported that living cells to prevent damage caused by metallic toxics seem to reside in the expression of proteins that export or chelate metals, such as the membrane-bound polypeptide specific for nickel and cobalt resistance induced under cobalt stress and allows cobalt efflux (Rodrigue et al.
2005). The effect of cadmium on the growth of the strain 2YB-25OH may be related to its deleterious effects on cell division, protein synthesis, and pronounced morphological aberrations (Slaveykova et al. 2009). Moreover, the growth was not affected much or very little affected in the presence of zinc, nickel, lead, copper, and chromium. This could be related to the role and degree of toxicity of each metal and the ability to precipitate at different $\mathrm{pH}$ (Ahemad 2012). In general, metals to act either as a micronutrient or as a toxicant, they have to be available for uptake by the bacterial cells. The metal species determines the solubility, bioavailability, and membrane transport, besides influencing the phenomenon of adsorption, oxidation/reduction, and exposure times (Worms et al. 2006). Usually, metal speciation is governed by $\mathrm{pH}$ of the medium (alkalinity or acidity), presence of $\mathrm{Ca} / \mathrm{Mg}$ ions, presence of organic matter, redox potential, and salinity (Markich et al. 2001). It is known that metals play a vital role in the metabolic processes of bacteria. Thus, some of them are essential and are required by the microorganisms as micronutrients and are known as trace elements (Rathnayake et al. 2009). They are involved in redox processes to stabilize molecules through electrostatic interactions, as catalysts in enzymatic reactions and regulating the osmotic balance. Thereby, zinc is structurally a vital constituent of several cellular enzymes and resistance to toxic levels of this metal can be due to extracellular accumulation, sequestration by metallothioneins, intracellular physical sequestration, or efflux mechanisms, such as P-type ATPase efflux system and RND-driven transporters system (Choudhury and Srivastava 2001). Though, some other heavy metals have no biological role and are detrimental to the organisms even at very low concentration. Their toxicity occurs through the displacement of essential metals from their native-binding sites or through ligand interactions. Eventually, toxicity can occur as a result of alterations in enzymes specificity and in the conformational structure of the nucleic acids and proteins and interference with oxidative phosphorylation and osmotic balance (Pereira et al. 2012).
Fig. 2 Evolution of the growth of the strain $2 \mathrm{YB}-25-\mathrm{OH}$ in the presence of metal ions at different $\mathrm{pH}$

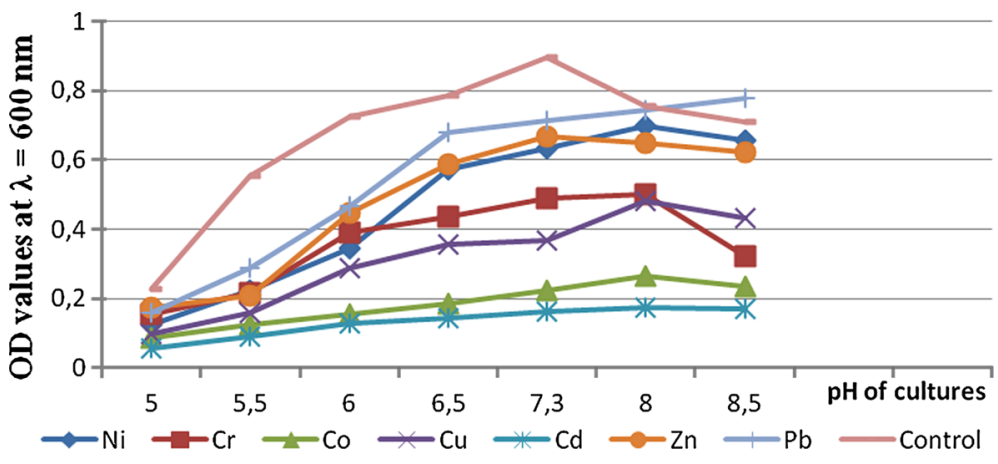




\section{Accumulation of metal ions by living bacterial cells}

Bioaccumulation is an active mode of metal uptake by living cells and depends on the metabolic activity of the cells referred to its intrinsic biochemical and structural properties, physiological and/or genetic adaptation, metal specification, availability, and toxicity (Krishna et al. 2012). The capacity of living cells to remove metal ions from culture medium is also significantly influenced by growth conditions, such as temperature, $\mathrm{pH}$, medium composition, and biomass concentrations (Chen and Ting 1995). Though, the results obtained from metals absorption study using living bacterial culture of the strain YB-25OH revealed higher amount of metal ions accumulation at higher $\mathrm{pH}$ and the values vary depending on the $\mathrm{pH}$ of medium (Table 2).The largest uptake capacity was obtained at $\mathrm{pH}$ 6-8.5 for copper, nickel, and zinc with values ranging from 51.45 to $83.90 \%, 52.59$ to $78.81 \%$, and 59.55 to $78.90 \%$, respectively. The maximum rate of metal ions accumulated by the isolate was obtained at $\mathrm{pH}$ 7.3. The living cells of the bacterium were able also to uptake 59.81-80.08\% of chromium and 58.09-79.41\% of cobalt at $\mathrm{pH}$ between 7.3 and 8.5. However, it has been reported that optimal $\mathrm{pH}$ for bioaccumulation of chromium, copper, zinc, and nickel by Micrococcus sp. was located at pH 7-7.2 (Congeevaram et al. 2007). Ademola et al. (2013) reported that Micrococcus luteus was not only resistant against copper, but also had the extensive capability of accumulating this heavy metal ion. Eventually, it has been reported that Micrococcus luteus highly accumulated nickel (Sandrin and Maier 2003). Sujitha and Jayanthi (2014) reported that living cells of Micrococcus sp. were able to accumulate $38.6 \mathrm{mg} \mathrm{L}^{-1}$ of chromium, $38.4 \mathrm{mg} \mathrm{L}^{-1}$ of zinc, and $36.3 \mathrm{mg} \mathrm{L}^{-1}$ of nickel. These results show that the accumulation amount of metal ions by the Micrococcus strain is relatively stable for the three heavy metals and are relatively far from ours. Beside that, some studies reported that bacteria are able to accumulate and compartmentalize copper in the cell's periplasm and the outer membrane and concluded the protective mechanism against copper due to productions of four proteins to overcome copper stress (Cooksey 1994; Mancini et al. 2015). Adebisi Musbaudeen et al. (2014) reported that Micrococcus luteus is not only resistant against copper and nickel, but also had the extensive capability of accumulating these heavy metals. Moreover, bacteria accumulate zinc by a fast but unspecific uptake mechanism and generally coupled with magnesium. Nevertheless, a significant absorption of lead was observed at $\mathrm{pH}$ 5.5-8.5 with an amount of 55.28-91.06 \%. Furthermore, the bacterial strain showed the lowest activity of cadmium uptake. This indicates that the accumulation of cadmium from nutrient broth media was also influenced by $\mathrm{pH}$ values. The maximum cadmium uptake capacity was shown at $\mathrm{pH} 6.5$ (38\%), while $\mathrm{pH} 8.5$ was suppressive. Thereby, it is important to mention that the $\mathrm{pH}$ of the broth media plays a major role in the extent of metal binding to microorganisms and greatly affects the degree of potential ligand that contribute to metal binding. Based on the results cited above, the isolate shows a high potential to accumulate heavy metals in particular lead and copper. It was also demonstrated that the species Micrococcus luteus has a greater ability to absorb lead Puyen et al. (2012). Furthermore, many researchers have reported on efficiency and mechanisms of bacteria to remove different metal ions, some of their statements could be comparable to this study. Richard et al. (2002) reported that copper and lead seemed to bind to materials on their cells surface. It has also been experimentally demonstrated that lead produced no toxic effect on Micrococcus luteus growth, and it was found in the cells wall and membrane. This indicates that lead was precipitated in an insoluble form that is localized to the cells membrane or cells surface (Levinson et al. 1996; Roane and Pepper 1999). This investigation may partly explain our results. Noghabi et al. (2007) reported that Gramnegative bacteria showed higher bioaccumulation capacity
Table 2 Heavy metals accumulated rates $(\%)$ by living bacterial cells at different $\mathrm{pHs}$

\begin{tabular}{llllllll}
\hline $\mathrm{pH}$ & Cadmium & Chromium & Cobalt & Copper & Lead & Nickel & Zinc \\
\hline 5 & 15.97 & 20.14 & 12.78 & 28.05 & 42.17 & 30.94 & 26.08 \\
5.5 & 18.10 & 31.02 & 18.22 & 44.07 & 55.28 & 33.12 & 46.03 \\
6 & 23.01 & 37.59 & 31.92 & 51.45 & 60.08 & 52.59 & 59.55 \\
6.5 & 38.00 & 43.01 & 44.50 & 54.22 & 73.06 & 63.01 & 66.47 \\
7.3 & 20.04 & 59.81 & 58.09 & 83.90 & 78.45 & 78.81 & 78.90 \\
8 & 10.17 & 66.57 & 79.41 & 78.13 & 89.20 & 72.57 & 72.70 \\
8.5 & 06.05 & 80.08 & 62.01 & 70.52 & 91.06 & 67.08 & 51.03 \\
\hline
\end{tabular}


to heavy metals than the Gram-positive counter parts due to their higher level of intrinsic metal resistance. This difference was based essentially on the chemical composition of their cell wall (Ahmad et al. 2005).

\section{Study of metal-ions removal capacity of dry bacterial cells (Biosorption)}

In general, biosorption is defined as an attribute of the inactive or dead microbial biomass to bind and concentrate metal ions even from highly dilute solutions (Vasudevan et al. 2001).The interactions between heavy metals and functional groups on the cell wall surface of bacterial biomass were confirmed by the Fourier transform infrared spectroscopy analysis, which indicate the possible removal of metal ions from the solution (Uniyal et al. 2013). This mechanism is based on non-enzymatic processes and characterized by the non-specific binding of metal ions to extracellular/cell surface-associated polysaccharides and proteins (Issazadeh et al. 2013). Though, the passive uptake is a rapid and reversible sequestering process of chemical compounds (Shim et al. 2015). Thus, the figures below show that the concentration of metal ions adsorbed by the strain in various metal concentrations decreases with the extension of the incubation time. According to the results obtained, the total bacterial adsorption in $25 \mu \mathrm{g} \mathrm{mL} \mathrm{m}^{-1}$ of zinc, chromium, and nickel solutions was very important immediately after inoculation. After $30 \mathrm{~min}$ of incubation, the amount of metal ions immobilized and captured by dead cells of the bacterium was also considerable and range from $20.46,22.5$, and $23.98 \mu \mathrm{g} \mathrm{mL}^{-1}$, respectively. A very slight decrease in the amount adsorbed after 60 min was noted. Beyond the mentioned removal times, zinc, chromium, and nickel concentrations sorbed decrease rapidly. Heavy-metal removal by the isolate in other solutions with higher concentrations 50 and $100 \mu \mathrm{g} \mathrm{mL}^{-1}$ started just after inoculation and the amount of metal ions adsorbed was relatively larger. The adsorption reached its maximum at $30 \mathrm{~min}$ and continued until $60 \mathrm{~min}$ of incubation but with a very discreet decrease. Finally, the amount of each metal immobilized in each solution was, respectively, as follows: 38.02 and $90.21 \mu \mathrm{g} \mathrm{mL}^{-1}$ for zinc, 39.78 and $89.23 \mu \mathrm{g} \mathrm{mL}^{-1}$ for chromium, and 47.19 and $86.83 \mu \mathrm{g} \mathrm{mL}^{-1}$ for nickel. These results appear to be linked directly to the $\mathrm{pH}$ of the solution, the time of contact, the heavy-metal concentrations, and the biomass. Leung et al. (2000) reported that Micrococcus luteus was able to adsorb heavy metals and indicated that the metal biosorption increased with increasing $\mathrm{pH}$ from 2 to 6 . Likewise, some studies reported that metal biosorption is

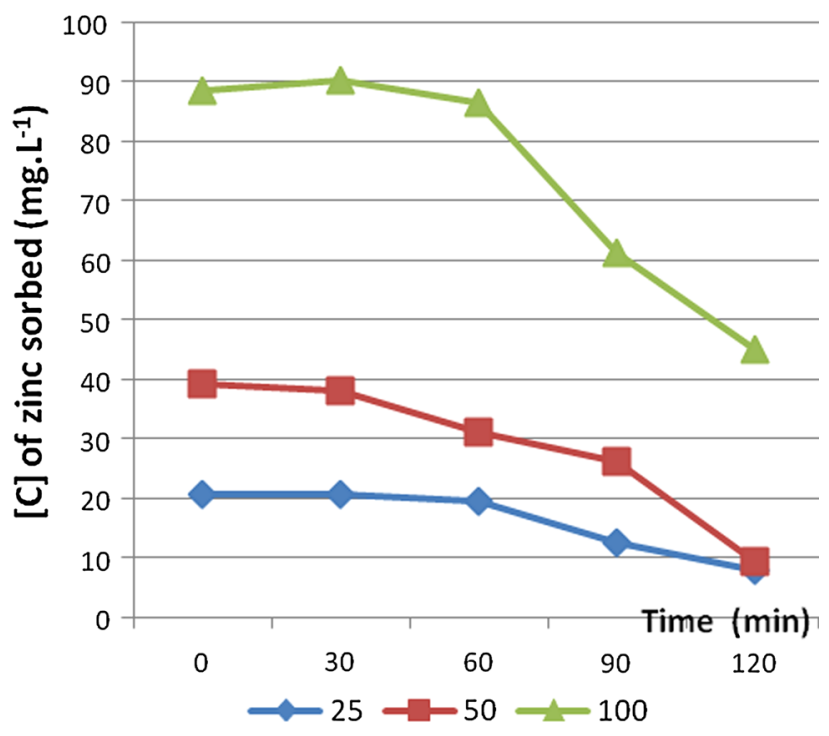

Fig. 3 Biosorption of zinc by dry cells of Micrococcus luteus

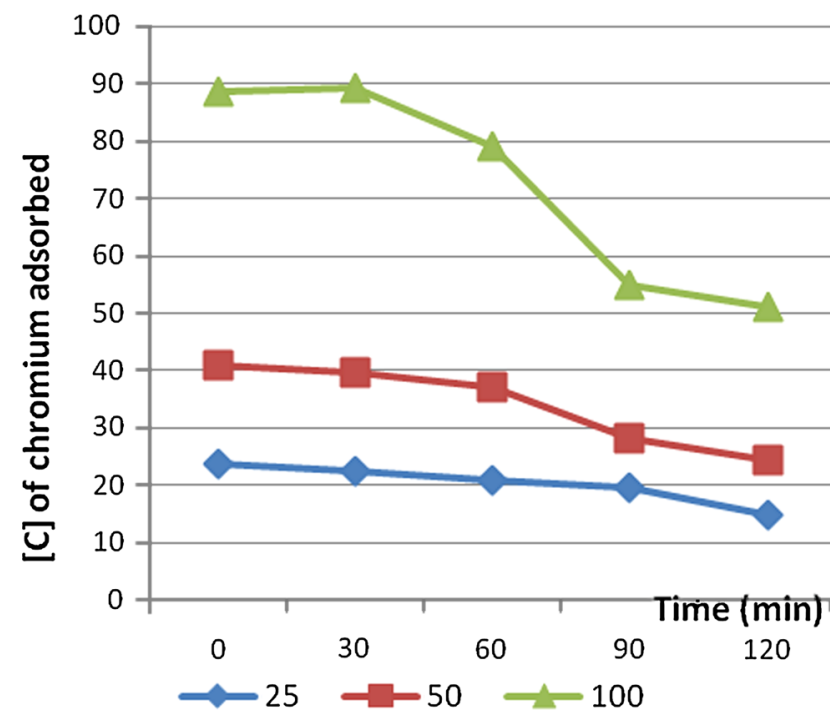

Fig. 4 Biosorption of chromium by dry cells of Micrococcus luteus

strongly $\mathrm{pH}$ dependent and demonstrate its effect on the nature of biomass binding sites, the activity of the functional groups in the biomass, the metal solubility, and the competition of metallic ions (Olaniran et al. 2013).Thereby, it is very important to clarify that heavymetal uptake for most of the biomass types, including bacteria, decline significantly when $\mathrm{pH}$ of the metal solutions is decreased from 6.0 to 2.5 , but increases when $\mathrm{pH}$ increases from 3.0 to 5.0 (Abbas et al. 2014a, b). However, 


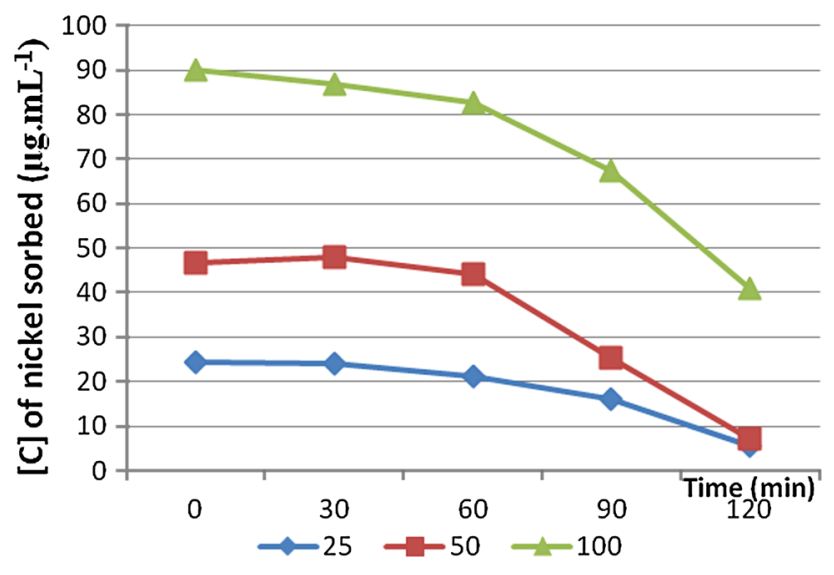

Fig. 5 Biosorption of nickel by dry cells of Micrococcus luteus

the biosorption of nickel, zinc, and chromium is often reduced at low pH values (Deng and Wang, 2012; Singh and Chopra 2014). Moreover, the results obtained between 90 and 120 min of incubation showed a significant amount of metal ions in the medium which could be explained by a reversible reaction, hence desorption of metal ions. Abyar et al. (2012) reported that glycoprotein materials in the cell wall of dead bacteria might be degraded with the extension of the incubation time which leads to the release of the adsorbed metals into the aqueous solution. Furthermore, it should be mentioned that the cell walls of the Gram-positive bacteria attach higher concentrations of metals than that of the Gram-negative bacteria, because of their thickness and anionic character which is mainly due to peptidoglycan, theichoic acid, and theichuronic acids (Vasudevan et al. 2001) (Figs. 3, 4, 5).

\section{Conclusion}

The bacterial strain 2YB-25OH isolated from wastewater of Oued EL HARRACH is multi-heavy-metal ions and antibiotics resistant. Its capacity to accumulate copper, nickel, zinc, chromium, cobalt, cadmium, and lead at different $\mathrm{pH}$ using living cells is considerable. Furthermore, the biosorption of zinc, chromium, and nickel by dry bacterial cells is also important. In all the cases, non-living cells showed higher activity to remove metal ions than living cells. However, further studies are needed; these results are very promising as a starting point for a potential application of this new strain of Micrococcus luteus in bioremediation of industrial effluent, sewage sludge, and industrial wastes.
Acknowledgments We are thankful to the Police Scientific Laboratory of Algiers and the Laboratory of Microbiology, IRD, France, for their help. We also like to thank Microbiology Laboratory Staff of the FSB/USTHB, Algiers, Algeria.

\section{References}

Abbas SH, Ismail IM, Mostafa TM, Abbas H, Sulaymon AH (2014a) Biosorption of heavy metals: a review. J Chem Sci Technol 3(4):74-102

Abbas SZ, Rafatullah M, Ismail N, Lalung J (2014b) Isolation, identification, and characterization of cadmium resistant $\mathrm{Pseu}$ domonas sp. M3 from industrial wastewater. J Waste Manag 54(12):1279-1287

Abicht HK, Gonskikh Y, Gerber SD, Solioz M (2013) Non-enzymic copper reduction by menaquinone enhances copper toxicity in Lactococcus lactis IL1403. Microbiology 159(6):1190-1197

Abyar H, Safahieh A, Zolgharnein H, Zamani I (2012) Isolation and identification of Achromobacter denitrificans and evaluation of its capacity in cadmium removal. Pol $\mathrm{J}$ Environ Stud 21(6): 1523-1527

Adebisi Musbaudeen S, Adebowale Toba O, Adeniyi Adewale O, Olasunkanmi II (2014) Bioaccumulation of heavy metals using selected heavy metal tolerant organisms isolated from dumpsite leachate. Nat Sci 12(10):101-106

Ahemad M (2012) Implications of bacterial resistance against heavy metals in bioremediation: a review. IIOAB J 3(3):39-46

Ahemad M, Malik A (2012) Bioaccumulation of heavy metals by zinc resistant bacteria isolated from agricultural soils irrigated with wastewater. Bacteriol J 2(1):12-21

Ahmad I, Hayat S, Ahmad A, Samiullah IA (2005) Effect of heavy metal on survival of certain groups of indigenous soil microbial population. J Appl Sci Environ Manag 9(1):115-121

American Public Health Association (1998) Standard methods for the examination of water andwastewater, 20th edn. APHA, Washington, $\mathrm{p} 1220$

Bashan LE, Bashan Y (2010) Immobilized microalgae for removing pollutants: review of practical aspects. Bioresour Technol 101(6):1611-1627

Bauer AW, Kirby WM, Sherris JC, Turck M (1966) Antibiotic susceptibility testing by a standardized single disc method. Am J Clin Pathol 45(4):493-496

Chen P, Ting YP (1995) Effect of heavy metal uptake on the electrokinetic properties of Saccharomyces cerevisiae. Biotechnol Lett 17(1):107-112

Choudhury R, Srivastava S (2001) Zinc resistance mechanisms in bacteria. Curr Sci 81(7):768-775

Congeevaram S, Dhanarani S, Park J, Dexilin M, Thamaraiselvi K (2007) Biosorption of chromium and nickel by heavy metal resistant fungal and bacterial isolates. J Hazard Mater 146(1-2):270-277

Cooksey DA (1994) Molecular mechanisms for copper resistance and accumulation in bacteria. FEMS Microbiol Rev 14:381-386

Deeb BE, Altalhi AD (2009) Degradative plasmid and heavy metal resistance plasmid naturally coexist in phenol and cyanide assimilating bacteria. Am J Biochem Biotechnol 5(2):84-93

Deng X, Wang P (2012) Isolation of marine bacteria highly resistant to mercury and their bioaccumulation process. Bioresour Technol 121:342-347 
Hans M, Mathews S, Mûcklich F, Solioz M (2016) Physicochemical properties of copper important for its antibacterial activity and development of a unified model. Biointerphases 11:018902. doi:10.1116/1.4935853

Issazadeh K, Jahanpour N, Pourghorbanali F, Raeisi G, Faekhondeh J (2013) Heavy metals resistance by bacterial strains. Ann Biol Res 4(2):60-63

Johncy RM, Hemambika B, Hemapriya J, Rajeshkannan V (2010) Comparative assessment of heavy metal removal by immobilized and dead bacterial cells: a biosorption approach. Glob J Environ Res 4(1):23-30

Kinare P, Shingadia H (2014) Screening of heavy metal resistant bacteria from Nale Lake of Vasai Taluka of Maharashtra. Int J Life Sci 2(2):139-142

Krishna MP, Varghese R, Babu AV, Hatha AAM (2012) Bioaccumulation of cadmium by Pseudomonas sp., isolated from metal polluted industrial region. Environ Res Eng Manag 61(3):58-64

Kumar A, Bisht BS, Joshi VD, Dhewa T (2011) Review on bioremediation of polluted environment: a management tool. Int J Environ Sci 1(6):1079-1093

Leung WC, Wong M-F, Chua H, Lo W, Yu PHF, Leung CK (2000) Removal and recovery of heavy metals by bacteria isolated from activated sludge treating industrial effluents and municipal wastewater. Water Sci Technol 41(12):233-240

Levinson HS, Mahler I, Blackwelder P, Hood T (1996) Lead resistance and sensitivity in Staphylococcus aureus. FEMS Microbiol Lett 145(3):421-425

Lucious S, Sathyapal ER, Anuradha V, Vijaya PP, Syed Ali M, Yogananth N, Rajan R, Parveen PK (2013) Heavy metal tolerance and antibiotic sensitivity of bacterial strains isolated from tannery effluent. Asian J Exp Bio Sci 4(4):597-606

Malik A, Ahemad M (2006) Genotoxicity of some wastewaters in India. Environ Toxicol Water Qual 10(4):287-293

Mancini S, Abicht HK, Gonskikh Y, Solioz M (2015) A copperinduced quinone degradation pathway provides protection against combined copper/quinone stress in Lactococcus lactis IL1403. Mol Microbiol 95(4):645-659

Markich SJ, Brown PL, Batley GE, Apte SC, Stauber JL (2001) Incorporating metal speciation and bioavailability into water quality guidelines for protecting aquatic ecosystems. Aust J Ecotoxicol 7(2):109-122

Mikolay A, Nies DH (2009) The ABC-transporter AtmA is involved in nickel and cobalt resistance of Cupriavidus metallidurans strain CH34. Antonie Van Leeuwenhoek 96(2):183-191

Morris RP, Nguyen L, Gatfield J, Visconti K, Nguyen K, Schnappinger D, Ehrt S, Liu Y, Heifets L, Pieters J, Schoolnik G, Thompson CJ (2005) Ancestral antibiotic resistance in $M y$ cobacterium tuberculosis. Proc Natl Acad Sci U S A 102(34):12200-12205

Nies DH (2003) Efflux mediated heavy metal resistance in prokaryotes. FEMS Microbiol Rev 27(2-3):313-339

Noghabi KA, Zahiri HS, Yoon SC (2007) The production of a coldinduced extracellular biopolymer by Pseudomonas fluorescens under various growth conditions and its role in heavy metals absorption. Process Biochem 42(5):847-855

Olaniran AO, Balgobind A, Pillay B (2013) Bioavailability of heavy metals in soil: impact on microbial biodegradation of organic compounds and possible improvement strategies. Int J Mol Sci 14(5):10197-10228
Pereira F, Krishnan KP, Sinha RK, Kerkar S (2012) Insights on metalmicrobe interactions Bacillus sp. and Chromohalobacter sp from a solar saltern. J Ecobiotechnol 4(1):14-24

Puyen ZM, Villagrasa E, Maldonado J, Diestra E, Esteve I, Solé A (2012) Biosorption of lead and copper by heavy-metal tolerant Micrococcus luteus DE2008. Bioresour Technol 126:233-237

Rajaganapathy V, Xavier F, Sreekumar D, Mandal PK (2011) Heavy metal contamination in soil, water and fodder and their presence in livestock and products. J Environ Sci Technol 4(3):234-249

Rajbanshi A (2008) Study on heavy metal resistant bacteria in Guheswori sewage treatment plant. Nature 6(1):52-57

Ranquet C, Ollagnier-de-Choudens S, Loiseau L, Barras F, Fontecave M (2007) Cobalt Stress in Escherichia coli. The effect on the iron-sulfur proteins. J Biol Chem 282(42):30442-30451

Rathnayake VN, Megharaj M, Bolan N, Naidu R (2009) Tolerance of heavy metals b Gram-positive soil bacteria. World Acad Sci Eng Technol 3(5):270-274

Richard WG, Krumholz-RUMHOLZ D, Matthew SC, Louis ST (2002) Heavy metal resistance pattern of frankia strains. Appl Environ Microbiol 68(2):923-927

Roane TM, Pepper IL (1999) Microbial responses to environmentally toxic cadmium. Microb Ecol 38(4):358-364

Rodrigue A, Effantin G, Mandrand-Berthelot MA (2005) Identification of renA (yohM), a nickel and cobalt resistance gene in Escherichia coli. J Bacteriol 187(8):2912-2916

Sandrin TR, Maier RM (2003) Impact of metals on the biodegradation of organic pollutants. Environ Health Perspect 111(8):1093-1101

Sheng-you L, Tzen-yuh C, Kuo-hsiang H, Ta-wei H (1999) Reexamination of the taxonomic status of Cunninghamia konishii and $C$. lanceolata based on the RFLPs of a chloroplast trnD-trnT spacer. Taiwan J For Sci 14(1):13-19

Shim J, Shea PJ, Jung IB, Oh BT, Cho M (2015) Potential of Pseudomonas sp. JH 51-2 tostabilize lead in mining site soil. J Environ Biol 36(3):695-701

Singh PP, Chopra AK (2014) Removal of $\mathrm{Zn}^{2+}$ and $\mathrm{Pb}^{2+}$ using new isolates of Bacillus spp. PPS03 and Bacillus subtilis PPS04 from Paper mill effluents using indigenously designed Bench-top Bioreactor. J Appl Nat Sci 6(1):47-56

Slaveykova VI, Dedieu K, Parthasarathy N, Hajdu R (2009) Effect of competing ions and complexing organic substances on the cadmium uptake by the soil bacterium Sinorhizobium meliloti. Environ Toxicol Chem 28(4):741-748

Spain A, Alm E (2003) Implications of microbial heavy metal tolerance in the environment. Rev Undergrad Res 2:1-6

Sujitha D, Jayanthi M (2014) Efficiency of immobilized microbial combination fo the bioremediation of tannery effluents in Vellore District, Tamil Nadu, India. Int J Adv Res Biol. Sci 1(8):113-120

Sulaimon AM, Akinwotu OO, Amoo OT (2015) Resistance of bacteria isolated from Awotan dumpsite leachate to heavy metals and selected antibiotics. Int $\mathbf{J}$ Res Pharm Biosci 2(9):8-17

Tamil Selvi A, Anjugam E, Archana Devi R, Madhan B, Kannappan S, Chandrasekaran B (2012) Isolation and characterization of bacteria from tannery effluent treatment plant and their tolerance to heavy metals and antibiotics. Asian J Exp Biol Sci 3(1):34-41 
Uniyal S, Rawat M, Rai JPN, Rai JPN (2013) Cadmium biosorption by Stenotrophomonas humi and Micrococcus luteus: kinetics, equilibrium and thermodynamic studies. Desalin Water Treat 51:7721-7731

Vasudevan V, Padmavathy N, Tewari SC, Dhingra J (2001) Biosorption of heavy metal ions. J Sci Ind Res 60(2):112-120

Vidali M (2001) Bioremediation. An overview. Pure Appl Chem 73(7):1163-1172
Wang Z, Ye Z, Zhang M, Bai X (2010) Degradation of 2, 4, 6trinitrotoluene (TNT) by immobilized microorganism-biological filter. Proc Biochem 45(6):993-1001

Worms I, Simon DF, Hassler CS, Wilkinson KJ (2006) Bioavailability of trace metals to aquatic microorganisms: importance of chemical, biological and physical processes on biouptake. Biochimie 88(11):1721-1731 